\title{
Modern and Contemporary Greek Literature Translated in Albanian: The Issues and the Expectations
}

\author{
Maklena Nika, Ph.D \\ Department of Greek Language, Faculty of Foreign Languages, University of Tirana, Albania
}

\section{Doi:10.5901/mjss.2015.v6n2s1p517}

\section{Abstract}

This study focuses on an overview of modern Greek literature translated in Albanian from 1920s until nowadays. It is the continuation of a specific study carried out for the Greek Language Centre in Thessaloniki (2007), in the framework of a program, supported by the Ministry of Culture, Greece, whose general scope was the translation of Greek literature in different languages. It relies on the categorization of the translated writers, in the topics treated by them, in the most favourite literary genre (prose, poetry or plays) as well as on the respective publishing houses. The analysis focuses on three main periods, the one before the liberation (1920-1945), the one during the communist regime in Albania (1945-1990) and on the post-communist period (1990-prezent), giving simultaneously even the reasons and the conditions that influenced on the translation of the literary works. The rest of this study treats the issues of the translation of these literary works (according to the respective periods), the translators that were engaged in the literary translations, as well as the Albanian reader's expectations towards this category of literature. At the end, there is the answer of the question: Does the corpus of Modern Greek literature satisfy the necessities of the Albanian readers and which are the challenges for the future?

\section{Introduction}

The presence of modernism in literature dates back in the second half of the XIX century. The first representatives were Joseph Conrad (1875-1955), Eduard Foster (1879-1970) and Ezra Pound (1885-1972). In Greece, it is difficult to specify the chronological definition of the period when this movement started, but the years 1910-1930 mark the starting point of this new literary tendency for Greek writers, which shook the foundations of the traditional literature at that time ${ }^{1}$. Modernism presence in Greece was delayed due to the fact that the traditional Greek literature found it difficult to accept this drastic change. In Greece as well as in Albania, there was a lack of the translated texts of the modern expression, and after the first translations of Marcel Proust, James Joyce, Franz Kafka, etc., the Greek writers would be in contact with the principles of modernism². More concretely, modernism starts its way in Greece in $1935^{3}$, with the poetic selection "Mythistorima" of Giorgos Seferis.

From this period until nowadays, there is a constellation of writers, poets and prose writers, who represented this literature in the Hellenistic land with dignity; therefore we can talk about a full development of modernism in Greece.

As the Albanian academic Rexhep Qosja states, the history of translation does not exist in Albania 4 . Furthermore, he explains that the historians of the European literature used to complain for about half a century that none of the European literatures had "fundamental works from the history of translations", monographs or studies on the translations which are made every day. He emphasizes the fact that Albanian language did not use to have and still does not have a historic background of translations.

\section{The Corpus of the Translations of Modern and Contemporary Greek Literature}

The study targets the corpus of the literary works written by the Greek writers after 1920s, including the literature for children translated in our country. This corpus includes the publications of the modern authors' works of a later period as

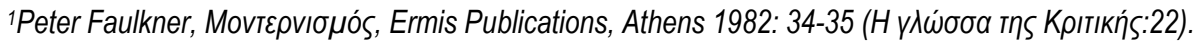

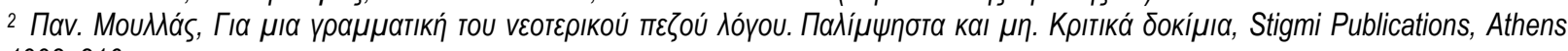
1992: 216.

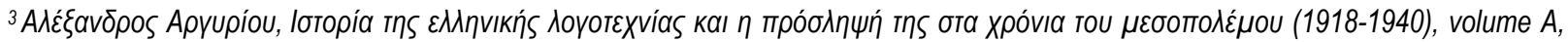
Kastanioti Publications, Athens 2002:534-535.

${ }^{4}$ Newspaper "Shqiptarja", Supplement "Rilindasi", dated 23/06/2013 
well as anthologies with poems and stories, and other anthologies which include poetic and prosaic entrances of this literature.

According to the research that has been carried out, there are 129 translated books in total, which belong to the genre of prose, poetry and plays, and $\mathbf{4}$ anthologies of the world literature including different Greek poets and prose writers.

Out of 129 translated publications, 59 of them belong to modern and contemporary Greek prose (53 novels, 6 selections with stories), 57 publications of the modern and contemporary Greek poetry, 6 anthologies with poems and 3 anthologies with stories and 4 plays, among which one belongs to Babis Tsikliropoulos, one to Giorgos Skourtis and one to Nikos Kazantzakis.

With regard to bilingual publications, there are nine selections with poems in Greek and Albanian language, highlighting Odysseas Elytis, Costantine P. Cavafy and some poets from Cyprus, who have received a special attention in the field of translation. The translator who worked harder to translate these poems is Niko Kacalidha, who brought a clear view of the literature in Cyprus through his successful translations. However, we should not forget even the two anthologies of the Cyprus prose and poetry, which were translated in Albanian by Stavri Dajo, the publications of the years 2000 and 2003.

\section{The Most Translated Writers and Perhaps the Most Favourite Ones for the Albanian Audience}

The number of the translated Greek writers in this category is 81 writers in total, out of whom 41 are prose writers and 40 are poets. Among them, 59 are male writers and 22 are female writers. It is obvious that they are in disproportion.

Among the most important prose writers, who presented a selection of stories, we highlight Antonis Samarakis, Antonis Dhesilas, Dhimitris Nolas, Zyranna Zateli, Menelaos Ludemis, and the writer from Epirus Lampros Malama.

Among the translations of the novels of the Greek literature, the work of Nikos Kazantzakis prevails. It results that 13 works of his have been translated (1 play Comedy, 9 novels and 3 travel notes). With a considerable difference form him we may also mention Kostas Varnalis (3 translations), Menelaos Ludemis (3 translations), Antonis Samarakis (3 translations), Omiros Avramidis and Lena Manda with 2 translations each. Albanian language records the translation of one of the works of the following authors: Nikos Athanasiadis, Kostas Asimakopoulos, Vasilis Vasiliko, Sotiris Dimitriou, Alki Zei, Konstantinos Theotokis, Melina Mercouri, Stratis Myrivilis, Alexandros Paradisis, Rea Galanaki, Kostas Hatziantoniou, Anteos Crysostomides, etc.

Modern and contemporary Greek literature is represented by famous and powerful names such as Giannis Manika, Giorgos Samartzidis, Theodosis Pierides, Kostas Mondi, Leta Koutsohera, Nasos Vagenas, Rita Boumi-Papa, Tasos Livaditis, Takis Varvitsiotis, Haris Vlavianos, Nikos Kavadias, Titos Patrikios, Antonis Fostieris, etc. without forgetting the father of the Greek Haiku Christos Toumanidis with 3 selections of poems. We may also mention the two popular poets Costandine P. Cavafy and Yiannis Ritsos with 4 and 7 selections of poems respectively, which were adapted in Albanian by different translators. We would like to mention specifically two great Nobel-winning poets Odysseas Elytis and Giorgos Seferis, who were introduced to Albanian readers with two translations each.

\section{A Historical Overview on Translations}

Our study covers a period which dates back from 1932 until 2014. The translation of the new Greek literature in Albanian language has gone through three historical phases which occurred in Albania.

a. The first phase refers to the years 1932-1945, when the novel of Stratis Myrivilis "The life in the Tomb", an incomplete translation by Falos Dh, published by the publishing house Drita, Korce 1932. This is a very poor phase regarding the presence of the modern Greek literature in Albania even though the entire Europe and Greece were experiencing a very intensive period of wars and modern ideas in art and literature. Apparently, Albania was far from this reality.

b. The second phase refers to the years 1945-1990, during which Albania was under the communist dictatorial regime, and only 21 literary works were translated. This vague background was created due to the literary limitation policy dictated by the communist system, which was oriented towards the translation of the ancient authors, such as Aeschylus, Sophocles, Euripides, Aristophanes, Plato, etc. During these difficult years for the Albanian intellectual, the following authors spoke Albanian: Kostas Valetas, Kostas Varnalis, Alki Zei, Nikos Kazantzakis ("Freedom or Death", "Zorba the Greek" published in Pristina 1978), Tasos Livaditis, Menelaos Loudemis, Lampros Malamas, Giannis Benekos, Rita Boumi-Papa, Alexandros Paradisis, Thedosis Pierides, Yannis Ritsos ("The man with a Carnation"), Antonis Samarakis and Vasilis Vasilikos near the 1990s. 
Apparently, these authors were not dangerous for the Albanian readers and would satisfy the ideology of the proletariat of that time. In this period, we can notice even two anthologies with poems, published in 1950 and 1980 respectively.

c. The third phase refers to the years 1990-2014, when the Albanian nation gave an end to the communist system and embraced the democratic system, followed with lots of changes in the political, economic and cultural life of the country. The number of the translations of the new Greek literature and of the modern one in particular grew significantly, as some new publishing houses appeared, apart from "Naim Frasheri" and "Ndermarrja Shteterore e Botimeve" ("The State Enterprise of Publications") which existed before 1990s. There are also republications of the old writers, after some elaborations in translation and at the same time other Greek poets and prose writers started to be translated in Albanian. In total, there are 98 translations of this literature with its climaxes in the years 2000, 2002, 2003, 2006, 2010 (when obviously the greatest number of publications was recorded, 14 translations), 2011 and 2014, when we received the 10 last publications (We would like to praise the publishing house Neraida, which, only during this year, published 7 translated works).

\section{The Translators}

Most of the translators who have translated in Albanian the abovementioned Greek authors are authentic translators and have also translated from other languages. The Greek writers were translated in Albanian by about 60 translators, such as Ismail Kadare, Xhevahir Spahiu, Aurel Plasari, Leonard Mero, Nonda Varfi, etc. who translate from other languages, mainly from French. The most popular translators who translated directly from the original are Niko Kacalidha, with 38 translations (mainly in the genre of poetry), Llambro Ruçi with 10 translations, Kleo Lati with 7 translations, Romeo Çollaku with 6 translations, Aleks Çaçi with 5 translations, Stavri Dajo, Aristotel Spiro, Vasil Koçi, Maklena Nika, Spiro Çomoro with 3 translations and many others with 2 and 1 translation. During these recent years, it has been noticed that the report of the translators has changed, as the old generation of the translators has been replaced by a new generation which has been adapted to all the modern and contemporary ideologies in literature, and with a great commitment to translate the entire Greek literature accurately and correctly.

\section{Publishing Houses}

There are 31 publishing houses, which deal with the publication of the books of modern and contemporary Greek literature in Albanian. Until 1990, in Albania, there were only state publishing houses such as "Naim Frasheri" with 18 publications. After 1990, and in continuation, private houses were established. The ones that covered translations systematically were: "Toena" with 29 publications, "Neraida" with 21 publications, "Albin" with 10 publications, "Mësonjëtorja" 9 publications, "Onufri" with 6 publications, "Globus R", "Rilindja" with 3 publications each, and "Horizont", "Milosao", "Zenit", "Egnatia" with 2 publications each. It is a pity that other publishing houses with an expanded activity in the field of publications do not publish translated works of the Greek authors because of their limiting policies oriented towards the foreign American and Hispanic literature, but even towards the European one.

The abovementioned publishing houses are among the biggest ones in Albania and of course, they have even the tools and the means to introduce and to promote in the market the respective publications. They take into consideration even the special request of the Albanian reader for this literature.

\section{The Expectations of the Albanian Reader}

To sum up, we can say that in Albania, the new translated Greek literature has been welcomed among the Albanian readers.

On the other hand, there are even some deficiencies regarding the complete form of this literature. There is an absence of the translated works written by Greek authors before 1930, as well as many other works written by contemporary authors. There are periods from the entire new Greek literature, which have not been represented with their writers, such as: The School of Seven Islands, Athens School, The generation of 1880 (2 very important works were translated from this generation such as: The Murderess of Alexandros Papadiamantis and The Pope Joan of Emmanuel Rhoides), The Generation of the 1920s (this period includes only the translations of some special authors), The generation of 1930 (represented by poets and prose-writers), the after-war literature, etc. We have to emphasize the fact that regarding the philological studies and the history of the New Greek literature there are not any translations of the 
respective studies from Greek language. I think that the translations of these studies and of the history of the New Greek literature are necessary for the readers, the critics and the scholars who deal with philological studies.

\section{Concluding Remarks}

In conclusion, the Albanian reader has to be kept informed about this literature through the promotions by the Ministry of Culture, accompanied with different cultural and artistic activities through the media, which has to be closer to these activities, and the arrangement of different informative programs for the public; through different funding by state and private entities for the translation of these works, without neglecting the essential role of the publishing houses.

\section{References}

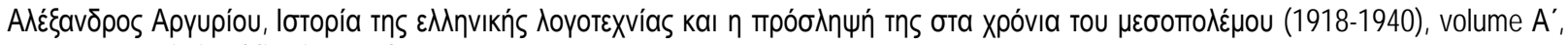
Kastanioti Publications, Athens 2002

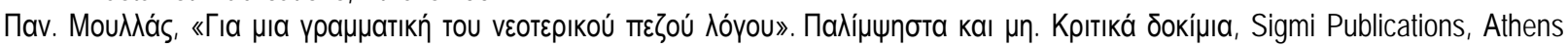
1992

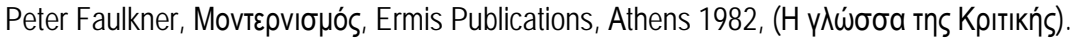

Newspaper "Shqiptarja", Supplemet Rilindasi, dated 23/06/2013.

http://www.bkt.al

www.ekebi.gr 